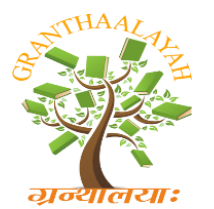

INTERNATIONAL JOURNAL OF RESEARCH GRANTHAALAYAH A knowledge Repository

Management

\title{
IMPACT OF COST OF WAR AGAINST TERRORISM ON THE DIFFERENT DETERMENTS OF FDI OF PAKISTAN
}

\author{
Khakan Najaf ${ }^{1}$, Rabia Najaf ${ }^{2}$ \\ ${ }^{1,2}$ Department of Accounting \& Finance, University of Lahore, Islamabad Campus, PAKISTAN
}

\begin{abstract}
In our study we have proven that FDI has crucial role in the growth of economy and the major source of the investment between developing and under developing countries, which is act as the bridge between saving-investment gaps. FDI is also way to increase the employment opportunities, economic growth and transfer of technology. In this study we have determined the different benefits of FDI for Pakistan .For this purpose we have taken the data from 1981 to 2011.we had collected the secondary data the basic purpose of this study is to check the influence of cost of war against the terrorism. We had applied two basic techniques ARMA model and OLS regression. Our result is showing that there is negative relationship between FDI and cost of war against the terrorism. However, control variables namely, trade openness; incentives, market size and exchange rate stability have positive impact on the inflows of FDI. On the other side, inflation rate has negative impact on the inflows of all developing and under developing country.
\end{abstract}

Keywords:

Incentives, FDI, ARMA model, OLS regression, Inflation rate.

Cite This Article: Khakan Najaf, and Rabia Najaf, "IMPACT OF COST OF WAR AGAINST TERRORISM ON THE DIFFERENT DETERMENTS OF FDI OF PAKISTAN" International Journal of Research - Granthaalayah, Vol. 4, No. 5 (2016): 156-168.

\section{INTRODUCTION}

From the last few decades, many scholars have been written about the decisiveness of FDI and its contribution about the developed and under developed country. FDI are consider as the source of investment for specially under developing country. Our study has proved that FDI has the main contribution in the poverty of the country. It is also way to enhance the transfer of technology, enhances of the jobs, and all types of managerial skills. According to Wafure and Nurudeen (2010) have discussed in their article that all these factors are contribution in the progress of the country. Latest policies are being framed to motive the foreign investors in these countries. Unfortunately, only few countries got benefit from the foreign investors. Most of the scholars have word out on this issue that why foreign investors did not invest in all these countries. After the evaluation of the nature of different policies it is concluded that lack of FDI 
become the reason of shortage of productivity, balance of payment and growth of the economy. According to different surveys, Pakistan are facing the problem of war against the terrorism activates from last few years. Since 2006, it is increase as the contamination of population. According to economic survey,(2011-2012) has shown that Pakistani economy is facing such type of problems like decline of productivity level, increase the unemployment level and internal migration. Since the 2000 Pakistan is facing the huge cost to against the war and its resources are also being utilized in these years of war. Economic survey, 2011-2012 has shown that from the last 11 years, Pakistan is facing the cost of war near about 68.927 billion. Due to this cost the GDP and investment level has dropped from $23.5 \%$.As the results of this downfall there is a lot of problems like creating of job etc. Current position is showing that these are negative impact of cost of war on the FDI inflows of Pakistan. poon (2000) has shown in his paper that MNC S are the way to select the position for the investment. Thus, it is proved that for the political stability the MNCS has the crucial role. Different researchers have proved that after the 1947, Pakistan is facing the FDI inflows due to political instability. Akhtar (2000) has proved in his study that political instability is known as the common phenomenon and it has affected the all the sectors of country and it is main reason to deterioration the trust of investors. Our study is trying to explore that unstable political environment is the reason that both domestic and foreign investors did not invest in Pakistan. Because investors are uncertain about their return investment. Foreign investor is the single source to help out the dilemma between saing-invesment. FDI has the source to provide the strength of national markets. Therefore, most of develop and under developed countries are keen regarding to attract the inflows of FDI.FDI has the crucial role for the improvement of the economic growth. Our study is providing that our country have not proper source for fulfill the gap between saving and investment. FDI is also known as the tool for the enhancement of domestic managerial skills. Hence, this study has proved that political instability is the major problem to maintain the stable FDI level. Electricity is also main reason that inflows of FDI is not stable .Government is trying their best to fulfilling the all promise relating to electricity but all in vain. Shortage of electricity is also affecting the domestic and foreign investors. Growth of Pakistan from last 20 to 25 years are proving that electricity is also factor which has impact on the poverty of development of Pakistan. In 1980 the inflows of FDI in Pakistan was 6.7\% and it had increased in 2003 it was 24\%-representing in 2009 it was risen in very small amount. Whenever the growth rate of FDI in developing country are $17 \$$ billion annually. During the 2004, their growth rate is $2.5 \$$ billion. Consequently, different scholars have proved that developing country has achieved the highest growth rate in 1997. In some years Pakistan got greater FDI due to its investment strategies. Because of restrained strategies the inflows level were increase in 1991.during the liberalization are it went up.

Table 1: Foreign Investment inflows in Pakistan (\$Million)

\begin{tabular}{|l|l|l|l|l|}
\hline Year & \multicolumn{1}{|c|}{$\begin{array}{c}\text { Greenfield } \\
\text { Investment }\end{array}$} & \multicolumn{1}{|c|}{$\begin{array}{c}\text { Privatization } \\
\text { proceeds }\end{array}$} & \multicolumn{1}{|c|}{ Total FDI } & $\begin{array}{c}\text { Private Portfolio } \\
\text { Investment }\end{array}$ \\
\hline $2002-03$ & 353.00 & 122.00 & 482.00 & -50.00 \\
\hline $2003-04$ & 621.00 & 171.00 & 792.00 & 26.00 \\
\hline $2004-05$ & 750.00 & 192.00 & 942.00 & -23.00 \\
\hline $2005-06$ & $1,161.00$ & 364.00 & $1,524.00$ & 152.00 \\
\hline $2006-07$ & $1,981.00$ & $1,542.00$ & $3,521.00$ & 353.00 \\
\hline
\end{tabular}




\begin{tabular}{|l|l|l|l|l|}
\hline $2007-08$ & $4,873.20$ & 262.40 & $5,132.60$ & $1,823.00$ \\
\hline $2008-09$ & $5,275.60$ & 131.20 & $5,401.80$ & 19.60 \\
\hline $2009-10$ & $3,717.90$ & 0.00 & $3,712.90$ & -510.20 \\
\hline $2010-11$ & $2,152.80$ & 0.00 & $2,152.80$ & 587.60 \\
\hline $2011-12$ & $1,571.6$ & 0.00 & $1,731.40$ & 344.6 \\
\hline $\begin{array}{l}2012-13 \\
\text { (Dec.) }\end{array}$ & 531.4 & 0.00 & 385.5 & -147.3 \\
\hline Total & $\mathbf{2 2 , 8 9 6 . 4}$ & $\mathbf{2 , 8 0 5 . 6 5}$ & $\mathbf{2 5 , 8 2 3 . 2}$ & $\mathbf{2 , 6 0 7 . 3}$ \\
\hline
\end{tabular}

Note: Pakistan's Fiscal Year runs from 1st July till 30th June

Source: Board of Investment Pakistan[6]

\section{OBJECTIVE}

Overall, we are also proving that Pakistan s economy has lot of way to increase the FDI inflows. The reason of the FDI slowdown is the mismanagement of the security. In this paper, we are exploring that relationship of cost of war against FDI inflows of Pakistan.

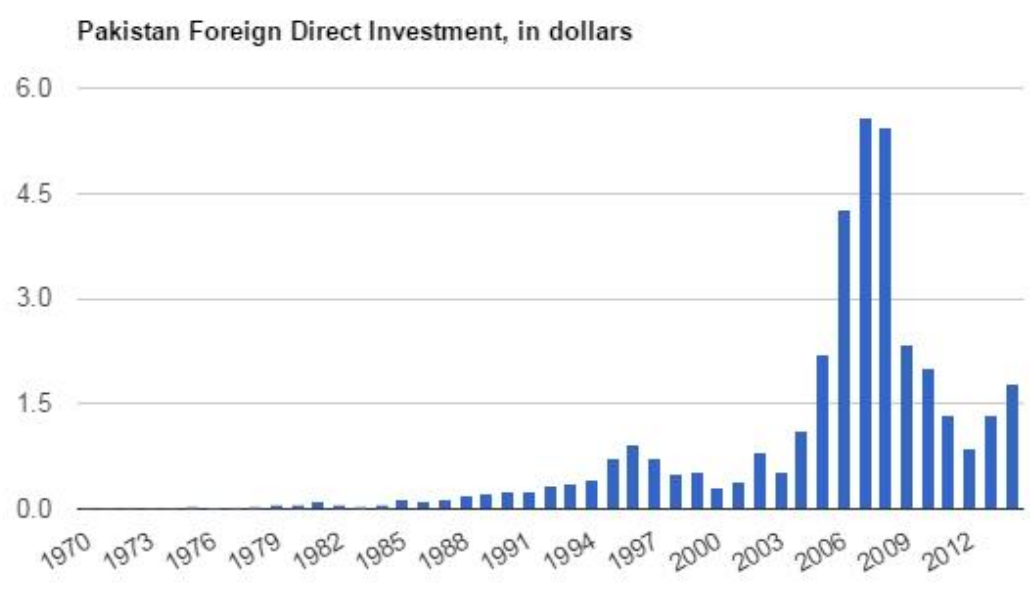

Source: TheGlobalEconomy.com, The World Bank

\section{PROBLEM STATEMENT}

FDI is known as the crucial role for the stimulation of the development of the poverty of all countries. All of the countries are not taking the same benefit from the inflows of FDI. Different research have proved that in Jordan the main determinates which effect on the FDI inflows are market size, inflation rate and exchange rate.

Scope of the study:

The purpose of this study is to find out the important determinates of FDI in developing and under developing country. We are also exploring political instability on the inflows of FDI. 


\section{LITERATURE REVIEW}

According to wafure Abu and Nurudeen, the impact of terrorism on the FDI of Nigeria stock exchange. The basic purpose of this papers to analysis the policies which have main role in the development of any country. They were collected the data from 1980 to 2000 and applied the ECM model and shown that terrorism had negative impact on the FDI of the nigera. In this paper, they had suggested that there is need of proper planning to increase the investors $\mathrm{s}$ confidence and remove terrorism[1].

According PJ Buckley, the impact of terrorism on the FDI of Jordan stock exchange. The basic purposes of this paper to analysis the policies which have main role in the development of any country. They were collected the data from 1981 to 2001 and applied the VCM model and shown that terrorism had negative impact on the FDI of the Jordan. In this paper, they had suggested that there is need of proper planning to increase the investment level and remove terrorism [2].

According Thompson E R, Jessie PH Poon, the impact of terrorism on the FDI of Iran stock exchange. The basic purposes of this paper to analysis the policies which have main role in the development of any country. They were collected the data from 1991 to 2010 and applied VAR model and shown that terrorism had negative impact on the FDI of the Iran .in this paper, they had suggested that there is need of proper policies to increase the investment level and remove terrorism[3].

According to M H Akhtar, the impact of terrorism on the FDI of France stock exchange. The basic purposes of this paper to analysis the policies which have main role in the development of any country. They were collected the data from 1998 to 2008 and applied ERACH model and shown that terrorism had negative impact on the FDI of the France .In this paper, they had suggested that there is need of proper system to increase the investment level and remove terrorism[4].

MH Khan, the impact of terrorism on the FDI of India stock exchange. The basic purposes of this paper to analysis the policies which have main role in the development of any country. He was collected the data from 1995 to 2005 and applied unit root test and shown that terrorism had negative impact on the FDI of the India .In this paper, they had suggested that there is need of proper research to increase the investment level and remove terrorism[5].

Husain I, the impact of terrorism on the FDI and stock exchange of Pakistan. The basic purposes of this paper to analysis the policies which have main role in the development of any country. He was collected the data from 1998 to 2004and applied GARCH model and shown that terrorism had negative impact on the FDI of the Pakistan .In this paper, he had suggested that there is need of proper strategies to increase the investment level and remove terrorism[6].

Yang JYY, Groenewold, N. and Tcha, M, the impact of terrorism on the FDI and stock exchange of china. The basic purposes of this paper to analysis the policies which have main role in the development of any country. They were collected the data from 1999 to 2009and applied EGARCH model and shown that terrorism had negative impact on the FDI of the China. In this 
paper, they had suggested that there is need of proper planning to increase the investment level and remove terrorism [7].

F Erdel, E Tatoglu, the impact of terrorism on the FDI and south Asian stock exchange. The basic purposes of this paper to analysis the policies which have main role in the development of any country. They were collected the data from 1989 to 2009and applied VAR model and shown that terrorism had negative impact on the FDI of the Asian stock exchange .In this paper, they had suggested that there is need of proper programs to increase the investment level and remove terrorism [8].

Fedderke JW, Romm, the impact of terrorism on the FDI and UK stock exchange. The basic purposes of this paper to analysis the policies which have main role in the development of any country. They were collected the data from 1980 to 2009and applied ECM model and shown that terrorism had negative impact on the FDI of the UK stock exchange .In this paper, they had suggested that there is need of proper system to increase the investment level and remove terrorism [9].

Moolman CE, Roos EL, LE Roux JC, DU Toit, CB, the impact of terrorism on the FDI and south Asian stock exchange the basic purpose of this paper to analysis the policies which have main role in the development of any country. They were collected the data from 1989 to 2009and applied VAR model and shown that terrorism had negative impact on the FDI of the south Asian .in this paper, they had suggested that there is need of proper strategies to increase the investment level and remove terrorism [10].

Swapna S. Sinha, the impact of terrorism on the FDI and UK stock exchange. The basic purposes of this paper to analysis the policies which have main role in the development of any country. They were collected the data from 1980 to 2009and applied ECM model and shown that terrorism had negative impact on the FDI of the UK stock exchange .In this paper, they had suggested that there is need of proper set up to increase the investment level and remove terrorism[11].

Mottaleb KA, the impact of terrorism on the FDI Syria the basic purpose of this papers to analysis the policies which have main role in the development of any country. They were collected the data from 1988 to 2008and applied ECM model and shown that terrorism had negative impact on the FDI of the Syria stock exchange .In this paper, they had suggested that there is need of proper policies to increase the investment level and remove terrorism [12].

E Demirhan and M. Masca, the impact of terrorism on the FDI and Turkey stock exchange. The basic purpose of this papers to analysis the policies which have main role in the development of any country. They were collected the data from 1981 to 2001 and run regression and shown that terrorism had negative impact on the FDI of the Turkey stock exchange. In this paper, they had suggested that there is need of proper system to increase the investment level and remove terrorism [13].

M B Masuku, T S Dl, the impact of terrorism on the FDI and OECD countries, the basic purpose of this paper to analysis the policies which have main role in the development of any country. 
They were collected the data from 1989 to 2009and applied VAR model and shown that terrorism had negative impact on the FDI of the OECD countries. In this paper, they had suggested that there is need of proper planning to increase the investment level and remove terrorism [14].

MA Yol, NT Teng, the impact of terrorism on the FDI Malaysia stock exchange, the basic purpose of this paper to analysis the policies which have main role in the development of any country. They were collected the data from 1985 to 2005and applied vicariate model and shown that terrorism had negative impact on the FDI of the Malaysia .In this paper, they had suggested that there is need of proper implementation to increase the investment level and remove terrorism [15].

DK Sen, CR Mohsin, the impact of terrorism on the FDI and Afghanistan stock exchange, the basic purpose of this paper to analysis the policies which have main role in the development of any country. They were collected the data from 1984 to 2003and applied VAR model and shown that terrorism had negative impact on the FDI of the Afghanistan .In this paper, they had suggested that there is need of proper policies to increase the investment level and remove terrorism[16].

$\mathrm{N}$ Shahrudin et al, the impact of terrorism on the FDI and Yemen countries, the basic purpose of this paper to analysis the policies which have main role in the development of any country. They were collected the data from 1982to 2005and applied multi regression model and shown that terrorism had negative impact on the FDI and Yemen countries. In this paper, they had suggested that there is need of proper policies to increase the investment level and remove terrorism [17].

Rihab and Lotfi, the impact of terrorism on the FDI and Libya countries the basic purpose of this paper to analysis the policies which have main role in the development of any country. They were collected the data from 1981 to 2001and applied VAR model and shown that terrorism had negative impact on the FDI of the Libya. In this paper, they had suggested that there is need of proper planning to increase the investment level and remove terrorism [18].

Z Shah, QM Ahmad, the impact of terrorism on the FDI and stock exchange of Thailand countries, the basic purpose of this paper to analysis the policies which have main role in the development of any country. They were collected the data from 1991to 2009and applied ECM model and shown that terrorism had negative impact on the FDI of the Thailand in this paper, they had suggested that there is need of proper system to increase the investment level and remove terrorism[19].

Nishat M, A Aqeel, the impact of terrorism on the FDI and Somalia, the basic purpose of this paper to analysis the policies which have main role in the development of any country. They were collected the data from 1999to 2009and applied unit root and co integration model and shown that terrorism had negative impact on the FDI of the Somalia in this paper, they had suggested that there is need of proper planning to increase the investment level and remove terrorism[20]. 
M Azam and L. Luqman, the impact of terrorism on the FDI and Australia stock exchange. The basic purposes of this paper to analysis the policies which have main role in the development of any country. They were collected the data from 1989 to 2006and applied Linear regression model and shown that terrorism had negative impact between Australia stock exchange and FDI .In this paper, they had suggested that there is need of proper program to increase the investment level and remove terrorism [21].

M Azam and N. R. Kahttak, the impact of terrorism on the FDI and Belgium stock exchange. The basic purposes of this paper to analysis the policies which have main role in the development of any country. They were collected the data from 1987 to 2004and linear regression model and shown that terrorism had negative impact on the FDI of the $n$ Belgium. In this paper, they had suggested that there is need of proper set up to increase the investment level and remove terrorism [22].

M Z Awan et al. A Nexus the impact of terrorism on the FDI and Egypt stock exchange. The basic purpose of this papers to analysis the policies which have main role in the development of any country. They were collected the data from 1984 to 2004and applied ECM model and shown that terrorism had negative impact on the FDI of the Egypt. In this paper, they had suggested that there is need of proper policies to increase the investment level and remove terrorism [23].

M Z Awan et al, the impact of terrorism on the FDI and Hong Kong stock exchange. The basic purposes of this paper to analysis the policies which have main role in the development of any country. They were collected the data from 1981 to 2001 and applied ECM model and shown that terrorism had negative impact on the FDI of the Hong Kong. In this paper, they had suggested that there is need of proper set up to increase the investment level and remove terrorism [24].

A Hakro and I.A. Gumro, the impact of terrorism on the FDI and Romania stock exchange. The basic purposes of this paper to analysis the policies which have main role in the development of any country. They were collected the data from 1988 to 2008and applied OLS model and shown that terrorism had negative impact on the FDI of the Romania. In this paper, they had suggested that there is need of proper systems to increase the investment level and remove terrorism [25].

S Agrawal, the impact of terrorism on the FDI and Mexico stock exchange. The basic purposes of this paper to analysis the policies which have main role in the development of any country. They were collected the data from 1999 to 2010and applied Autogressive model and shown that terrorism had negative impact on the FDI of the Mexico. In this paper, they had suggested that there is need of proper planning to increase the investment level and remove terrorism [26].

\section{GAPS IN THE LITERATURE}

1) In the previous studies not any researchers had found the solution to improve the FDI in under developing countries.

2) In the prior studies, different researchers are not exploring the policies to control such types of the issues.

3) All the scholars' should have discussed about the recommendation that how can foreign investors. 


\section{ANALYSIS}

I have read the different regarding to impact cost of war on the poverty of paksitan.In this research paper, we have found that there is negative relationship between FDI inflows and cost of war of terrorism.

\section{MATERIALS AND METHODS}

We have collected the data from 1982 to 2011 from the FBR, BOI, FBS, SBP and economic survey of paksitan. We have collected the different descriptive statistical for the dependent and indepent variables. We have been collected correlation matric for purpose of checking the correlation between both variables. In the time series we mostly used the unit root test for the purpose of checking the stationary between them. We have employed the least square model for the propose of measuring the relationship between cost of war and FDI inflows in Pakistan.

\section{EQUATION}

$\mathrm{nFDI}=\beta 0+\beta 1$ LnTerror $+\beta 2 \mathrm{Pol}+\beta 3 \mathrm{LnElec}+$ $\beta 4$ RGDP $+\beta 5$ Trade $+\beta 6$ Exch $+\beta 7$ Inf $+\beta 8$ Incen + $\mathrm{Ut}$

Where:

LnFDI = Inflows of foreign direct investment in million rupees

LnTerror $=$ Cost of war against terrorism in million rupees

Pol $=$ Value of 0 for civilian rule and value of 1 for military rule LnElec $=$ Electricity production in $\mathrm{KWH}$

RGDP $=$ Real growth rate of gross domestic product in percentage

Trade $=$ Trade openness calculated as ratio of exports to Imports

Exch = Annual growth rate in exchange rate of Rupee $/ \$$

Inf $=$ Annual rate of inflation in percentage

Incen $=1$ for the period of 1989 to 2010,0 otherwise 
Table 3: ADF Stationary Unit Root Test for Variables

\begin{tabular}{|c|c|c|c|}
\hline Variables & $\begin{array}{c}\text { T-ADF } \\
\text { Statistics }\end{array}$ & Critical Values & Decision \\
\hline LnFDI & $\begin{array}{l}-4.843916 \\
(0.0034)\end{array}$ & $\begin{array}{l}2 \% \text { level }=-4.356069 \\
5 \% \text { level }=-3.595027 \\
11 \% \quad \text { level }\end{array}$ & $\begin{array}{r}\text { Stationary at level } \\
=\quad-3.2334567\end{array}$ \\
\hline LnTerror & $\begin{array}{c}-5.444723 \\
(0.0002)\end{array}$ & $\begin{array}{l}2 \% \text { level }=-3.679323 \\
5 \% \text { level }=-2.967768 \\
11 \% \text { level }=-2.622988\end{array}$ & $\begin{array}{l}\text { Stationary at } 1 \text { st } \\
\text { difference }\end{array}$ \\
\hline \multirow[t]{2}{*}{ LnElec } & \multirow{2}{*}{$\begin{array}{l}-4.488018 \\
(0.0014)\end{array}$} & $\begin{array}{l}2 \% \text { level }=-3.670171 \\
5 \% \text { level }=-2.963973\end{array}$ & \multirow{2}{*}{$\begin{array}{r}\text { Stationary at level } \\
=\quad-2.621008\end{array}$} \\
\hline & & $11 \% \quad$ level & \\
\hline RGDP & $\begin{array}{c}-4.032379 \\
(0.0042)\end{array}$ & $\begin{array}{l}2 \% \text { level }=-3.670171 \\
5 \% \text { level }=-2.963973 \\
11 \% \text { level }=-2.621008\end{array}$ & Stationary at level \\
\hline Trade & $\begin{array}{l}-5.423868 \\
(0.0002)\end{array}$ & $\begin{array}{l}2 \% \text { level }=-3.679323 \\
5 \% \text { level }=-2.967768 \\
11 \% \text { level }=-2.622988\end{array}$ & $\begin{array}{l}\text { Stationary at } 1 \text { st } \\
\text { difference }\end{array}$ \\
\hline Exch & $\begin{array}{c}-4.113374 \\
(0.0034)\end{array}$ & $\begin{array}{l}2 \% \text { level }=-3.670171 \\
5 \% \text { level }=-2.963973 \\
11 \% \text { level }=-2.621008\end{array}$ & Stationary at level \\
\hline $\operatorname{Inf}$ & $\begin{array}{l}-3.753902 \\
(0.0092)\end{array}$ & $\begin{array}{l}2 \% \text { level }=-3.711458 \\
5 \% \text { level }=-2.981039 \\
11 \% \text { level }=-2.6299067\end{array}$ & Stationary at level \\
\hline
\end{tabular}

Table 4: OLS Regression Estimates

Dependent Variable: LNFDI

Method: Least Squares

Included observations: 31 after adjustments

$\begin{array}{crrrl}\text { Variable } & \text { Coefficient } & \text { Std. Error } & \text { t-Statistic } & \text { Prob. } \\ & & & & \\ \text { LNTERROR } & -0.009943 & 0.020867 & -0.476472 & 0.6385 \\ \text { POL } & -0.586468 & 0.301844 & -1.942955 & 0.06498^{*} * * \\ \text { LNELEC } & 2.524509 & 0.315307 & 8.006536 & 0.0000 * \\ \text { RGDP } & 0.097664 & 0.035628 & 2.741118 & 0.0118 * * \\ \text { TRADE } & 0.126976 & 0.026526 & 4.786926 & 0.0002^{*} \\ \text { EXCH } & 0.023207 & 0.011461 & 2.024927 & 0.05523^{* * *} \\ \text { INF } & 0.016171 & 0.026124 & 0.619002 & 0.5424 \\ \text { INCEN } & 1.037962 & 0.384702 & 2.698096 & 0.0132^{* *} \\ \text { C } & -25.24073 & 3.419255 & -7.381935 & 0.1000^{*}\end{array}$

R-squared

Adjusted R-squared

S.E. of regression

Sum squared resid

Log likelihood

F-statistic

Prob(F-statistic)
0.966204 Mean dependent var

0.953914 S.D. dependent var

0.317438 Akaike info criterion

2.216858 Durbin-Watson stat

$-3.099706$

78.61874

0.000000
5.965066

1.478669

0.780627

2.366092

* Significant at 1 Percent.

** Significant at 5 Percent.

*** Significant at 10 Percent 
Table 5: One-Sample Kolmogorov-Smirnov Test

Unstandardized Residual

$\mathrm{N}$

Normal Parameters ${ }^{2}$

Mean

.0000000

Std. Deviation

.27182688

Most Extreme Differences

Absolute

.095

Positive

.092

Negative

Kolmogorov-Smimov Z

.531

Asymp. Sig. (2-tailed)

959

a. Test distribution is Normal.

Table 6: Coefficients Table

Variable

LnTerror

Pol

LnElec

RGDP

Trade

Exch

Inf

Incen

a. Dependent Variable: LnFDI

b.
Collinearity Statistics

\section{Tolerance}

.209

.148

.098

.707

.222

.668

.321

.108
VIF

4.812

6.826

9.306

1.418

4.519

1.496

3.128

9.382

\section{INTERPRETATION}

Firstly, it is important to analyses the nature of the data and check the stationary of the different variables. Therefore, we have applies the (ADF) test to check the stationary of the data and checked the stationary between dependent and independent variables. Its result is shown in the table no 3.our results are showing that FDI, exchange rate, GDP, electricity generation were stationary at level and cost of war against terrorism are stationary at the first differene. After checking the stationary level we have applied the ARMA model to check the relationship between dependent and independent variable. For the estimation of the parameters, we have applied the least square model. The results of the ARMA model is showing the moving average term and showing that lag value of FDI is not affecting the FDI inflows. Hence, ARMA model is not suitable for this purpose. Therefore, we have employed the OLS model. OLS is useful to estimate the relationship between dependent and independent variable. The value of Durbin Watson, adjusted $\mathrm{R}$-square, loglikehood and F-statistics are showing the better result than 
ARMA model. The results of OLS are showing in table no 4 . The value of adjusted $r$ square is 0.96 which is showing the variation about $96 \%$ it is showing that there is variation occurring in the inflows of Pakistan. Durbin Watson is showing the mathematical equation is more accurate its value is 2.38 . The value of $\mathrm{A} / \mathrm{C}$ is 0.79 which is showing that model is goodness of fit and it is suitable to make the inference.

The following results are showing that coat of war has negative sign on the FDI inflows of

Pakistan. According to Agrawal (2011) has shown in his report that terrorism has negative impact on the FDI inflows of allover the world. From 10 years Pakistan inflows is going down .this is one of the main hindrances that FDI inflows is wear in Pakistan. Pakistan and different foreign investors are facing the uncertain about to investment in Pakistan. Our results are showing that there is negative relationship between political instability and FDI inflows in Pakistan. Most of the investors just invest in that country where return is safe and sound.

Moreover, there is positive relationship between exchange rate stability and FDI inflows. According to Dare et.al (2004) that exchange rate encourages the inflows of FDI. Regression results are also showing that fiscal policy has the positive impact on the FDI inflows. While, inflation rate has negative relationship with FDI inflows. Our results are showing that electricity and inflow of FDI has the positive relationship. The high magnitude is showing the electricity has the crucial role to attract the FDI. The shortage of electricity created the problem for the businessmen. Our study is also showing that there is positive relationship between market size and inflows of Pakistan. According to Lukman and Awan (2006) has estimated that there is significant relationship between trade openness and FDI inflows of Pakistan.

\section{DISCUSSION}

In this paper, we have discussed about the different determinates of FDI in our country and we have found the impact of these on the economy of Pakistan. Our study is showing that there is positive relationship between political instability, exchange rate stability, electricity generation and fiscal incentives and providing that there is negative relationship between cost of war against terrorism and inflation rate also has the negative relationship with FDI and providing that there is negative relationship between cost of war against terrorism and inflation rate also has the negative relationship with FDI. The main focus of this study is to analysis the impact of cost of war against the different terrorism activities. In different literature there have not been discussed about it. Our study is showing that these variables have impacted on the inflows of Pakistan. Therefore, there is need to focus on these variables for the attraction of inflows of FDI.

Suggestions:

1) On the basic of empirical results we have taken the results that there is need of regulatory authorizes to measure the cost of war against terrorism activities.

2) Government should make proper policies to overcome such type of the problem.

3) Government should also focus on the political institutions to increase the inflows of FDI.

4) Government should adopt the best democratic principles for the attraction of FDI. 


\section{REFERENCES}

[1] Wafure Abu and Nurudeen, Determinants of Foreign Direct Investment in Nigeria: An Empirical Analysis, Global Journal of Human Social Science, Vol. 10 Issue 1 (Ver1.0), April 2010, PP. 26-34 (2010).Economic Surveys of Pakistan.www.finance.gov.pk, September 2011.

[2] PJ Buckley. Motives of Foreign Firms in Pakistan. The Lahore Journal of Economics, Vol.5, No.2 (2000).

[3] Thompson E R, Jessie PH Poon (2000). ASEANafter the Crisis: Links between Foreign Direct Investment and Regulatory Chang e.ASEAN Economic Bulletin, 17:14.

[4] M H Akhtar. The Determinants of Foreign Direct Investment in Pakistan: An Econometric Analysis. The Lahore Journal of Economics, Vol.5, No.1, (2000).United Nations Statistical Division Dataset.www.unstats.un.org/unsd/default.htm,September 2011.

[5] MH Khan. Rural Poverty in Developing Countries. Finance and Development, December 2007, volume 37, Number 4(2000).

[6] Husain I (1999). Pakistan: The Economy of an Elitist State, Oxford University Press. Tcha M. A Note on Australia's Inward and Outward Direct Foreign Investment. Papersin Regional Science 78, 89-100 (1999).

[7] Yang JYY, Groenewold, N. and Tcha, M. The Determinants of Foreign Direct Investment in Australia. Economic Record 76, 45-54(2000).

[8] F Erdel, E Tatoglu. Locational Determinants of Foreign Direct Investment in an emerging Market Economy: Evidence from Turkey. Multinational Business Review, Vol.1 0, No.1 (2002).

[9] Fedderke JW, Romm AT Growth Impact and determinants of foreign direct investment into South Africa. University of Cape Town, WorkingPaper: 12 (2004).

[10] Moolman CE, Roos EL, LE Roux JC, DU Toit,CB Foreign Direct Investment: South Africa's Elixir of Life? Department of Economics, University of Pretoria, Working Paper Series (2006).

[11] Swapna S. Sinha. Comparative Analysis of FDI in China and India: Can Laggards Learn from Leaders? www.bookpump.com/dps/pdfb/1123981b.pd, (2007).

[12] Mottaleb KA Determinants of Foreign Direct Investment and Its Impact on Economic Growth in Developing Countries, MPRAPaper No.9457 (2007).

[13] E Demirhan and M. Masca. Parague Economic Papers (2008).

[14] M B Masuku, T S Dlamini. Determinants of foreign direct investment inflows in Swaziland. Journal of Development and Agricultural Economics, Vol. 1(5), pp. 177-184, November, 2009. Academic Journals (2009).

[15] MA Yol, NT Teng. Estimating the Domestic Determinants of Foreign Direct Investment Inflows in Malaysia: Evidence from Co integration and Error-Correction Model.Jurnal Pengurusan 28, pp. 3-22 (2009).

[16] DK Sen, CR Mohsin. FDI in the Context ofSAARC Nations with Particular Reference to Bangladesh: An Analytical Study. The Bangladesh Accountant/January-March2010 (2010).

[17] N Shahrudin et al. Determinants of Foreign Direct Investment in Malaysia: What MattersMost? International Review of Business Research Papers Volume 6. Number 6.December 2010 pp.235-245 (2010). 
[18] Rihab and Lotfi. The institutional and cultural determinants of foreign direct investment in transition countries. Journal of Research in International Business and Management(ISSN:2251-0028)Vol. 1(2) pp. 171 -182August (2011).

[19] Z Shah, QM Ahmad. The Determinants of Foreign Direct Investment in Pakistan: an Empirical Investigation. The Pakistan Development Review 42: 4 Part II (Winter 2003) pp. 697-714 (2003).

[20] Nishat M, A Aqeel. The Determinants of Foreign Direct Investment in Pakistan. The Pakistan Development Review 43: 4, Part II (Winter2004) pp. 651-664 (2004).

[21] M Azam and L. Luqman. Determinants of Foreign Direct Investment in India, Indonesia and Pakistan: A Quantitative Approach. Journal of Managerial Sciences, Volume IV, Number 1 (2006).

[22] M Azam and N. R. Kahttak. Social and Political Factors Effects On Foreign Direct Investment In Pakistan (1971 -2005). Gomal University Journal of Research, 25-1: 4650(2009).

[23] M Z Awan et al. A Nexus between Foreign Direct Investment \& Pakistan's Economies. International Research Journal of Finance and Economics, ISSN 1450-2887 Issue 52(2010).

[24] MZ Awan et al. Economic determinants of foreign direct investment (FDI) in commodity producing sector: A case study of Pakistan.African Journal of Business Management, Vol. 5(2), pp. 537-545, 18 January (2011).

[25] AN Hakro and I.A. Gumro. Determinants of Foreign Direct Investment Flows to Pakistan. The Journal of Developing Areas, Volume 44, Number 2, spring 2011, pp.217242 (2011). State Bank of Pakistan (SBP). www.sbp.org.pk,September 2011.Board of Investment (BOI) Pakistan.www.pakboi.gov.pk, September 2011.Federal Bureau of Statistics (FBS) Pakistan.www.statpak.gov.pk, September 2011. World Bank Development Indicators.www.worldbank.org, September 2011.International Monetary Fund (IMF). www.Imf.org,September 2011.USDA/ERS International Macroeconomic Dataset. www.ers.usda.gov, September 2011.

[26] S Agrawal. The Impact of Terrorism on Foreign Direct Investment: Which Sectors are More Vulnerable? CMC Senior Theses. Paper 124(2011). Website of Economy Watch.www.economywatch.com, September 2011. 